\title{
Arginine Vasopressin Potentiates Adrenocorticotropin Release Induced by Ovine Corticotropin-releasing Factor
}

\author{
C. Rowan DeBold, William R. Sheldon, \\ G. Stephen DeCherney, Richard V. Jackson, \\ A. Nancye Alexander, Wylie Vale, Jean Rivier, \\ and David N. Orth \\ Department of Medicine, Vanderbilt University Medical Center, \\ Nashville, Tennessee 37232; Peptide Biology Laboratory, \\ The Salk Institute, San Diego, California 92138
}

bstract. Arginine vasopressin (AVP) stimulates ACTH release in man and acts synergistically with synthetic ovine corticotropin-releasing factor (OCRF) in vitro. This study was designed to examine in man the combined effects of synthetic AVP (10 U intramuscularly) and oCRF (1 $\mu \mathrm{g} / \mathrm{kg}$ intravenously) on ACTH release. Five normal male volunteers participated in five separate experiments: (a) AVP alone; (b) oCRF alone; (c) AVP followed by oCRF 15 min later; (d) simultaneous AVP and oCRF; and $(e)$ insulin-induced hypoglycemia. Plasma immunoreactive ACTH (IR-ACTH) and IR-cortisol were measured for $4 \mathrm{~h}$ after injection of each hormone; basal levels for all subjects were $\leq 9 \pm 1.2 \mathrm{pg} / \mathrm{ml}$ and $4.9 \pm 0.4$ $\mu \mathrm{g} / \mathrm{dl}$ (mean $\pm \mathrm{SE}$ ), respectively. AVP and oCRF, when given individually, caused rapid rises in IR-ACTH to similar peak levels of $25 \pm 6.6$ and $33 \pm 4.6 \mathrm{pg} / \mathrm{ml}$, respectively. AVP given 15 min before oCRF caused a 2.6 -fold potentiation of the oCRF response, with a peak IR-ACTH of $85 \pm 4.6 \mathrm{pg} / \mathrm{ml}$. AVP given at the same time as oCRF produced a fourfold potentiation of the peak IR-ACTH

Dr. DeBold is the recipient of National Research Fellowship Award 1-F32-CA06939 from the National Cancer Institute. Dr. Sheldon is the recipient of a Fellowship Award from Research Training in Diabetes and Endocrinology grant 5-T32-AM07061. Dr. DeCherney is the recipient of National Research Fellow Award 1-F32-AM06758 from the National Institute of Arthritis, Diabetes, Digestive and Kidney Disease. Dr. Jackson is an Applied Health Sciences Fellow, National Health and Medical Research Council of Australia. Dr. Rivier and Dr. Vale are Clayton Foundation Investigators.

Address all correspondence to Dr. DeBold, Endocrinology Division, A4215 Vanderbilt Medical Center North, Nashville, TN, 37232. 1983.

Received for publication 11 July 1983 and in revised form 11 October

J. Clin. Invest.

(c) The American Society for Clinical Investigation, Inc.

$0021-9738 / 84 / 02 / 0533 / 06 \quad \$ 1.00$

Volume 73, February 1984, 533-538 response to $132 \pm 11 \mathrm{pg} / \mathrm{ml}$. These ACTH responses were far greater than those previously observed after 30 -fold greater doses of oCRF alone. By way of comparison, insulin-induced hypoglycemia caused a peak IR-ACTH of $169 \pm 20 \mathrm{pg} / \mathrm{ml}$. IR-ACTH returned to base line at 60 90 min after AVP alone, whereas the prolonged effect of oCRF was apparent whether it was given alone or in combination with AVP. The mean peak IR-cortisol responses to AVP, oCRF, and AVP given 15 min before oCRF were similar $(16.5 \pm 0.9,16.4 \pm 2.3$, and $18.5 \pm 0.8$ $\mu \mathrm{g} / \mathrm{dl}$, respectively), but the peak IR-cortisol responses to AVP and oCRF given simultaneously and to insulininduced hypoglycemia were 1.5 and 1.7 times greater, respectively. IR-cortisol returned to base line within 2$3 \mathrm{~h}$ after AVP alone, but remained elevated for at least $4 \mathrm{~h}$ after OCRF alone or in combination with AVP.

These results indicate that AVP acts synergistically with oCRF to release ACTH in man and suggest that AVP may play a physiologic role in modulating the ACTH response mediated by corticotropin-releasing factor.

\section{Introduction}

Corticotropin-releasing factor (CRF), ${ }^{1}$ a 41 -amino acid peptide isolated from ovine hypothalamic extracts $(1,2)$, is a physiologically important mediator of ACTH secretion $(3,4)$. In man, ovine CRF (oCRF) is a potent stimulus to ACTH secretion (5) and has a prolonged duration of action (6) that is probably due to its prolonged circulating half-life in plasma (7).

Vasopressin (VP), which, like CRF, has been localized in cells of the paraventricular nucleus of the hypothalamus (8), also releases ACTH, albeit with less potency than CRF, from anterior pituitary cells in vitro $(1,9-13)$ and in vivo in rats

1. Abbreviations used in this paper: AVP, arginine vasopressin; CRF, corticotropin-releasing factor, IR, immunoreactive; oCRF, ovine corticotropin-releasing factor; VP, vasopressin. 
(14-16) and humans (17-18). Although shown to be an ACTH secretagogue, the physiologic role played by VP in the regulation of ACTH secretion is uncertain $(3,19,20)$. Studies in Brattleboro rats, which genetically lack VP but have ACTH-releasing activity in extracts of their hypothalami and secrete ACTH in response to stress, suggest that VP plays only a minor role (21-23).

Over the last decade, an hypothesis has emerged that VP may modulate the ACTH response to CRF and may be only one of several factors influencing ACTH secretion $(3,19,23$, 24). Early studies showed that low doses of VP potentiated the ACTH-releasing activity of hypothalamic extracts in rats (25). This work has been confirmed in vitro with hypothalamic extracts from Brattleboro rats as the source of $\operatorname{CRF}(21,22)$ and with synthetic oCRF $(4,13,26)$. The mechanism of this synergistic effect may be through potentiation of cyclic AMP accumulation induced by CRF (26).

Based on this evidence, a role for VP as a physiologic modulator of ACTH secretion should be considered. We designed this study to examine the effect of VP and oCRF, administered singly or in combination, on ACTH release in man, as assessed by plasma immunoreactive-ACTH (IR-ACTH) and IR-cortisol concentrations.

\section{Methods}

Subjects. Five healthy male volunteer subjects, aged $21-40$ yr (mean, 30.4 ) and weighing $69-91 \mathrm{~kg}$ (mean, 77.2), who were taking no medications and had normal physical examinations, unremarkable medical histories, and normal blood cell counts, serum chemistry profiles, urinalyses, and electrocardiograms, participated in five studies, each separated by at least $5 \mathrm{~d}$.

Study design. The experiments were performed in the Vanderbilt Clinical Research Center in late afternoon, a time when we anticipated that basal pituitary ACTH secretion and, therefore, plasma ACTH and cortisol levels would be relatively low. The study was conducted in a single-blind fashion, with each subject participating in five experiments: (a) synthetic arginine vasopressin (AVP) alone; (b) oCRF alone; (c) AVP followed by oCRF 15 min later; $(d)$ simultaneous AVP and oCRF; and (e) insulin-induced hypoglycemia. Subjects were fasted after an early light lunch. Each experiment was performed with the subjects supine. At about 4:00 p.m., intravenous infusion lines were established in each forearm through which sterile $154 \mathrm{mM} \mathrm{NaCl}$ solution was infused at a rate to replace the blood volume withdrawn. At least $30 \mathrm{~min}$ after the infusion lines were established, the first of two basal blood samples was withdrawn. $15 \mathrm{~min}$ later, the second basal blood sample was obtained. In the first three studies, an intramuscular injection of 10 pressor units of synthetic AVP (Pitressin, Parke, Davis \& Co., Detroit, MI) or a similar volume of saline placebo was injected into the deltoid muscle of the arm opposite that from which the blood samples were taken. $15 \mathrm{~min}$ later, after two additional blood samples were obtained, an injection of oCRF ( $1 \mu \mathrm{g} / \mathrm{kg}$ body weight) or an equal volume of vehicle placebo was injected as an intravenous bolus into the same arm into which the AVP was injected. Blood samples were obtained at intervals over the next 4 $h$. Blood pressure and pulse were recorded automatically every 2-5 $\mathrm{min}$ for the first $30 \mathrm{~min}$ after AVP injection and every 5-10 min for the next $2 \mathrm{~h}$. In the fourth study, AVP and CRF were given simultaneously.
In the fifth study, $0.15 \mathrm{U} / \mathrm{kg}$ of regular insulin (Iletin, Eli Lilly \& Co., Indianapolis, IN) alone was injected intravenously. Blood glucose levels were measured at the bedside every $5 \mathrm{~min}$ with an automatic Beckman glucose analyzer (Beckman Instruments, Inc., Fullerton, CA). All subjects had glucose nadirs of $<40 \mathrm{mg} / \mathrm{dl}$ and experienced typical symptoms of hypoglycemia. On the day following each study, subjects returned for a urinalysis, blood cell count, and serum chemistry profile.

The study protocol was approved under an Investigational Exemption for a New Drug by the Food and Drug Administration, U. S. Public Health Service, by the Vanderbilt University Committee for the Protection of Human Subjects-Health Sciences, and by the Salk Institute Human Investigations Committee. Each subject gave his written informed consent prior to commencing the study.

$o C R F$. Synthetic oCRF (Lot \#96-116-20) was dissolved at a concentration of $1 \mathrm{mg} / \mathrm{ml}$ in $0.001 \mathrm{~N} \mathrm{HCl}, 154 \mathrm{mM} \mathrm{NaCl}$, containing $10 \%$ (wt/vol) mannitol U.S. Pharmacopeia, 0.25\% (wt/vol) human serum albumin U.S. Pharmacopeia, and $0.9 \%$ (vol/vol) benzyl alcohol, was sterilized by filtration through a $0.22-\mu \mathrm{m}$ filter (Millex-GS, Millipore Corp., Bedford, MA), and was lyophilized and stored at $-20^{\circ} \mathrm{C}$ in singledose vials until reconstituted with sterile $0.001 \mathrm{~N} \mathrm{HCl}, 0.9 \%$ benzyl alcohol immediately before use.

Hormone assays. Cortisol was measured in unextracted plasma by solid-phase radioimmunoassay (Micromedic Systems, Inc., Horsham, PA). ACTH was measured by radioimmunoassay in unextracted plasma (27) by using antibody IgG-ACTH-1 (IgG Corp., Nashville, TN), which is directed at the ACTH-(5-18) sequence. The intraassay coefficients of variation were 7.3 and $4.6 \%$ at 15 and $60 \mathrm{pg} / \mathrm{ml}$, respectively $(n=5)$, and the respective interassay coefficients of variation were 9.2 and $8.6 \%$ $(n=5)$.

Statistical analysis. For the purpose of calculating mean values for the increments in hormone levels, undetectable levels of IR-ACTH (i.e., $<10 \mathrm{pg} / \mathrm{ml}$ ) were assigned a value half that of the detection limit (i.e., $5 \mathrm{pg} / \mathrm{ml}$ ). All IR-cortisol levels were at or above the limit of detectability, which was $1.3 \mu \mathrm{g} / \mathrm{ml}$. Mean peak responses were compared by analysis of variance and Duncan's multiple range test (28).

\section{Results}

Plasma IR-ACTH levels. Basal plasma IR-ACTH for all subjects was $\leq 9 \pm 1.2 \mathrm{pg} / \mathrm{ml}$ (mean $\pm \mathrm{SE})$. AVP and oCRF, when given individually, caused rapid rises in plasma IR-ACTH (Fig. 1) to similar mean peak levels of $25 \pm 6.6$ and $33 \pm 4.6 \mathrm{pg} / \mathrm{ml}$, respectively (Fig. 3). The peak response occurred $15 \mathrm{~min}$ after AVP and 15-60 min after oCRF administration. The duration of the IR-ACTH response to oCRF was longer than to AVP; IR-ACTH levels returned to basal level within $75 \mathrm{~min}$ after AVP, but remained elevated for up to $4 \mathrm{~h}$ after oCRF (Fig. 1).

When AVP was given 15 min before oCRF, the mean peak IR-ACTH level $(85 \pm 4.6 \mathrm{pg} / \mathrm{ml})$ was only 2.6 times greater than after oCRF alone $(P<0.01$, Fig. 3). Compared with oCRF alone, simultaneous administration of AVP and oCRF caused a possibly more rapid rise in plasma IR-ACTH (Fig. 1) to a fourfold greater mean peak of $132 \pm 11 \mathrm{pg} / \mathrm{ml}(P<0.01$, Fig. 3). Following either combination of AVP and oCRF, IR-ACTH dropped to levels seen after oCRF alone by $60-90 \mathrm{~min}$ and remained elevated for up to $4 \mathrm{~h}$ (Fig. 1). Insulin-induced hy- 


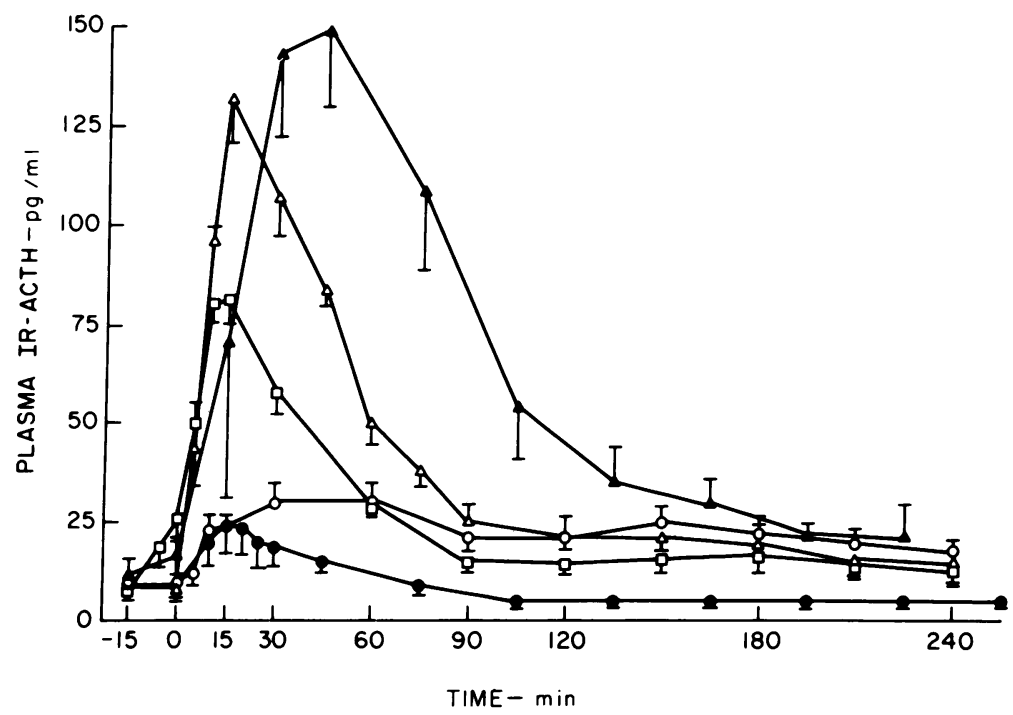

Figure 1. Plasma IR-ACTH concentrations after administration of synthetic AVP and OCRF, alone and in combination, or insulin-induced hypoglycemia. ๑, AVP, 10 pressor units given intramuscularly at time $0 ; \bigcirc, O C R F, 1$ $\mu \mathrm{g} / \mathrm{kg}$ body weight given intravenously at time 0 ; $\square$, AVP, given at time -15 min $[A V P(-15)]$ plus oCRF given at time $0 ; \triangle, A V P$ plus $O C R F$, both given at time 0 ; and $\Delta$, regular insulin, $0.15 \mathrm{U} / \mathrm{kg}$ intravenously given at time $-15 \mathrm{~min}$. The same five normal volunteer subjects participated in all five experiments. Symbols represent the mean of five values; brackets indicate SEM. poglycemia caused the greatest rise in plasma IR-ACTH (Fig. 1) to a mean peak of $169 \pm 20 \mathrm{pg} / \mathrm{ml}$ (Fig. 3). This level was 5.1 times greater than after oCRF alone $(P<0.01)$, but only 1.3 times greater than after simultaneous oCRF and AVP ( $P$ $<0.05$ ). The duration of the response also appeared greater than that to oCRF or AVP alone or in combination.

Plasma IR-cortisol levels. Basal plasma IR-cortisol for all subjects was $4.9 \pm 0.4 \mu \mathrm{g} / \mathrm{dl}$ (mean $\pm \mathrm{SE})$. AVP alone caused a brief rise in IR-cortisol to $16.5 \pm 0.9 \mu \mathrm{g} / \mathrm{dl}$ at $30 \mathrm{~min}$, followed by a rapid decline to base-line level by $180 \mathrm{~min}$ (Figs. 2 and 3). oCRF stimulated a similar rise in plasma IR-cortisol to a mean peak of $16.4 \pm 2.3 \mu \mathrm{g} / \mathrm{dl}$ (Fig. 3), but the level peaked later and remained elevated for at least $4 \mathrm{~h}$ (Fig. 2). After simultaneous AVP and oCRF, the mean peak IR-cortisol was $22.8 \pm 2.1 \mu \mathrm{g} /$ dl, 1.4 times greater than after AVP or oCRF alone $(P<0.05$,
Fig. 3). When AVP was injected $15 \mathrm{~min}$ before oCRF, the combination resulted in an intermediate mean peak IR-cortisol of $18.5 \pm 0.8 \mu \mathrm{g} / \mathrm{dl}$, which was significantly less $(P<0.05)$ than that after simultaneous administration, and did not differ significantly from that after either AVP or oCRF alone (Fig. 3). In all three studies in which $O C R F$ was given, IR-cortisol remained elevated for at least $4 \mathrm{~h}$ (Fig. 2). The mean peak IRcortisol concentration after insulin-induced hypoglycemia was $26.1 \pm 3.8 \mu \mathrm{g} / \mathrm{dl}$ (Fig. 3), which was slightly but not significantly greater than that after simultaneous AVP and oCRF administration; the levels also remained slightly higher for the duration of the experiment (Fig. 2).

Signs and symptoms. All subjects who received AVP alone or in combination with oCRF demonstrated a marked facial pallor, but had no symptoms or changes in blood pressure or

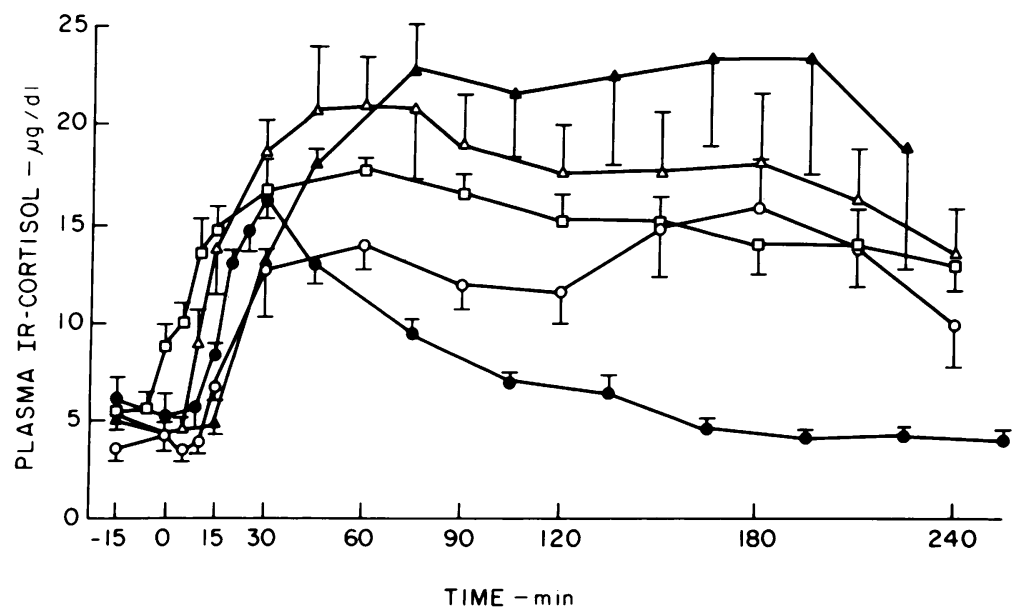

Figure 2. Plasma IR-cortisol concentrations after administration of synthetic AVP and oCRF, alone and in combination, or insulin-induced hypoglycemia. Data are plotted as in Fig. 1. 

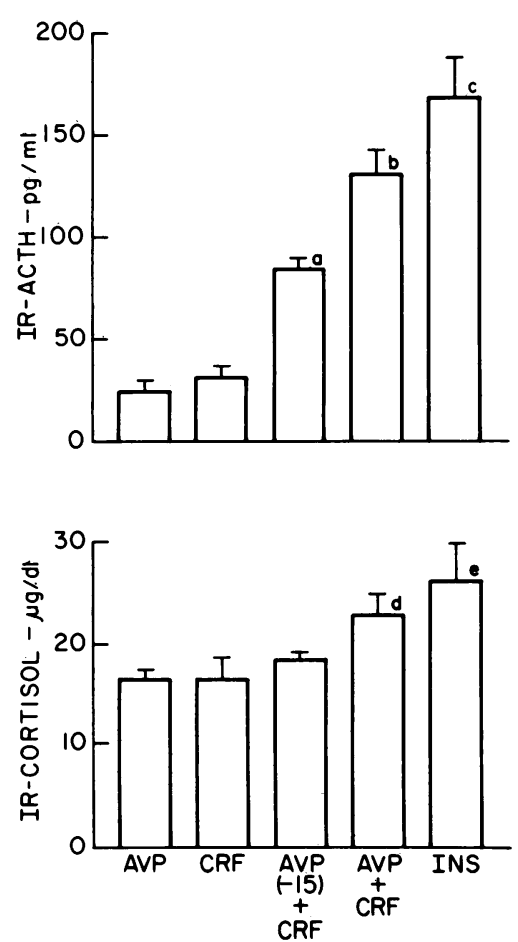

Figure 3. Peak concentrations of plasma IR-ACTH and IR-cortisol after administration of synthetic AVP and OCRF, alone and in combination, or insulin-induced hypoglycemia. The same five subjects participated in all five experiments. Each bar represents the mean of the peak concentration reached in each subject at any time after AVP 10 pressor units intramuscularly, oCRF $1 \mu \mathrm{g} / \mathrm{kg}$ body weight intravenously, AVP given 15 min before oCRF [AVP( -15$)$ ] plus $O C R F$ given at time 0, AVP plus OCRF given simultaneously, and insulininduced hypoglycemia (INS); brackets indicate SEM; $a, P<0.01$ compared with AVP and oCRF; $b, P<0.01$ compared with AVP, OCRF, and AVP(-15) plus oCRF; $c, P<0.01$ compared with AVP, OCRF, and AVP $(-15)$ plus $O C R F$ and $P<0.05$ compared with AVP plus oCRF; $d, P>0.05$ compared with AVP, oCRF, AVP( $(-15)$ plus $\circ C R F$, and INS; $e, P<0.05$ compared with AVP, oCRF, and AVP(-15) plus OCRF.

pulse rate. Symptoms experienced by subjects receiving oCRF alone were absent or minimal and consisted, when present, only of mild facial flushing and transient dyspnea. There was no difference in symptoms when AVP was given simultaneously with or $15 \mathrm{~min}$ before oCRF. Analysis of blood cell counts, serum chemistry profiles, and urinalyses of the subjects on the day following each experiment showed no consistent changes from base-line values.

\section{Discussion}

In this study, we have compared the plasma IR-ACTH and IRcortisol response in man to AVP and oCRF, given alone and in combination. When these hormones were given individually in similar doses (oCRF, 14.8-19.5 nmol, mean $16.5 \mathrm{nmol}$; AVP, 10 pressor units, or $23 \mathrm{nmol}$ ), they caused similar rates of rise and mean peak levels of plasma IR-ACTH and IR-cortisol. In contrast, the ACTH-releasing potency of OCRF has been found to be 5-10 times greater than that of AVP on a molar basis in rat anterior pituitary cells (1) and in intact rats (29). This discrepancy could be due to different routes of administration, species differences in rates of metabolism, or species differences in pituitary responsiveness to these hormones. Another explanation is that AVP might cause release of endogenous CRF in addition to having a direct action on the pituitary (30). The subjects in the present study had no signs or symptoms of stress after AVP injection, so a nonspecific stress response appears to be an unlikely explanation for their IR-ACTH and IR-cortisol responses to AVP.

Simultaneous administration of AVP and oCRF caused a synergistic effect on ACTH secretion, resulting in a fourfold greater plasma IR-ACTH response than after either agent alone. This response is similar to that described in intact rats (25) and rat anterior pituitary cells $(4,13,26)$, and adds further support to the hypothesis that AVP is an important physiologic modulator of ACTH secretion.

Maximum ACTH secretion occurred when AVP and oCRF were administered simultaneously. When oCRF was given 15 min after AVP, which is the time of maximum plasma IRACTH response to AVP, the plasma IR-ACTH peak was reduced to only 2.6 times the response to oCRF alone. Thus, it appears that the corticotroph must be exposed to both agents simultaneously to produce a maximal synergistic effect. The mechanism of this synergistic effect may be related to potentiation by AVP of intracellular cAMP levels stimulated by oCRF (26), but it is not clear why a synergistic rather than an additive effect is observed.

In the experiments in which oCRF was administered, IRACTH levels remained elevated for at least $4 \mathrm{~h}$. In contrast, the effect of AVP was brief, with IR-ACTH returning to base line within $75 \mathrm{~min}$. This prolonged effect of oCRF has been noted before (6) and is probably due to its slow metabolic clearance (7).

For comparison, another potent stimulus to ACTH secretion, insulin-induced hypoglycemia, was studied. The peak IR-ACTH level following insulin was 1.3 times greater and of longer duration than that observed after simultaneous administration of AVP and oCRF. This finding could reflect the fact that the pituitary was exposed to less than maximally stimulating concentrations of $O C R F$ and/or AVP or that the duration of exposure was less. Doses of oCRF up to 30 times greater than those used in this study cause still higher plasma IR-ACTH responses (5). Alternatively, hypoglycemia might cause the release of additional ACTH secretogogues, whose combined effect might be greater than that of oCRF and AVP.

The IR-cortisol response to these agents reflected the peak IR-ACTH responses, although the differences were not as 
marked. AVP, oCRF, and AVP given 15 min before oCRF caused similar peak plasma IR-cortisol levels, whereas simultaneous AVP and OCRF caused a 1.4-fold greater IR-cortisol level. Insulin-induced hypoglycemia produced a still greater response. The cortisol response to these agents was not directly proportional to the IR-ACTH response, indicating that plasma ACTH levels of only $25-50 \mathrm{pg} / \mathrm{ml}$ produce near maximal, acute stimulation of adrenal steroidogenesis.

The sequence for human CRF has recently been deduced from the nucleotide sequence of the gene (31). It differs in seven amino acid residues from oCRF, but is identical to rat CRF (32). Until synthetic oCRF and synthetic human CRF are tested in man, one cannot assume that their activities are identical.

In conclusion, the ACTH response to oCRF in man is potentiated by AVP, suggesting a physiologic role for AVP as a modulator of ACTH secretion.

\section{Acknowledgments}

We thank IgG Corporation, Nashville, TN for the gift of anticorticotropin serum IgG-ACTH-1; Ms. Ann C. Zielinski, Ms. Julann Krakau, and Ms. Barbara J. Sherrell for their excellent technical assistance; and Ms. Loretta C. Scruggs for transcribing the manuscript.

These studies were supported in part by U. S. Public Health Service research grants 5-R01-CA1 1685 and 5-R25-CA19429 from the National Cancer Institute, 5-M01-RR00095 from the General Research Center Branch of the National Institutes of Health, and 5-R01-AM26741 from the National Institute of Arthritis, Diabetes, Digestive and Kidney Disease. Research at the Peptide Biology Laboratory was conducted in part by the Clayton Foundation for Research, California Division.

\section{References}

1. Vale, W., J. Spiess, C. Rivier, and J. Rivier. 1981. Characterization of a 41-residue ovine hypothalamic peptide that stimulates secretion of corticotropin and $\beta$-endorphin. Science (Wash. DC). 213:1394-1397.

2. Spiess, J., J. Rivier, C. Rivier, and W. Vale. 1981. Primary structure of corticotropin-releasing factor from ovine hypothalamus. Proc. Natl. Acad. Sci. USA. 78:6517-6521.

3. Yasuda, N., M. A. Greer, and T. Aizawa. 1982. Corticotropinreleasing factor. Endocr. Rev. 3:123-140.

4. Vale, W. W., C. Rivier, J. Spiess, M. R. Brown, and J. Rivier. 1983. Corticotropin-releasing factor. In Brain Peptides. D. Krieger, M. Brownstein, and J. Martin, editors. John Wiley \& Sons, Inc., New York. 961-974.

5. Orth, D. N., R. V. Jackson, G. S. DeCherney, C. R. DeBold, A. N. Alexander, D. P. Island, J. Rivier, C. Rivier, J. Spiess, and W. Vale. 1983. Effect of synthetic ovine corticotropin-releasing factor: dose response of plasma adrenocorticotropin and cortisol. J. Clin. Invest. 71:587-595.

6. DeBold, C. R., G. S. DeCherney, R. V. Jackson, W. R. Sheldon, A. N. Alexander, D. P. Island, J. Rivier, W. Vale, and D. N. Orth. 1983. Effect of synthetic ovine corticotropin-releasing factor. prolonged duration of action and biphasic response of plasma adrenocorticotropin and cortisol. J. Clin. Endocrinol. Metab. 57:294-298.
7. Nicholson, W. E., G. S. DeCherney, R. V. Jackson, C. R. DeBold, H. Uderman, A. N. Alexander, J. Rivier, W. Vale, and D. N. Orth. 1983. Plasma distribution, disappearance half-time, metabolic clearance rate and degradation of synthetic ovine corticotropin-releasing factor in man. J. Clin. Endocrinol. Metab. 57:1263-1269.

8. Roth, K. A., E. Weber, and J. D. Barchas. 1982. Immunoreactive corticotropin releasing factor (CRF) and vasopressin are colocalized in a subpopulation of the immunoreactive vasopressin cells in the paraventricular nucleus of the hypothalamus. Life Sci. 31:1857-1860.

9. Portanova, R., and G. Sayers. 1973. Isolated pituitary cells: CRFlike activity of neurohypophysial and related polypeptides. Proc. Soc. Exp. Biol. Med. 143:661-666.

10. Pearlmutter, A. F., E. Rapino, and M. Saffran. 1974. A semiautomated in vitro assay for CRF: activities of peptides related to oxytocin and vasopressin. Neuroendocrinology. 15:106-119.

11. Vale, W., and C. Rivier. 1977. Substances modulating the secretion of ACTH by cultured anterior pituitary cells. Fed. Proc. 36:20942099.

12. Gillies, G., T. B. van Wimersma Greidanus, and P. J. Lowry. 1978. Characterization of rat stalk median eminence vasopressin and its involvement in adrenocorticotropin release. Endocrinology. 103:528534.

13. Gillies, G. E., E. A. Linton, and P. J. Lowry. 1982. Corticotropin releasing activity of the new CRF is potentiated several times by vasopressin. Nature (Lond.). 299:355-357.

14. McCann, S. M. 1957. The ACTH-releasing activity of extracts of the posterior lobe of the pituitary in vivo. Endocrinology. 60:664676.

15. Rivier, C., W. Vale, and R. Guillemin. 1973. An in vivo corticotropin-releasing (CRF) factor assay based on plasma levels of radioimmunoassayable ACTH. Proc. Soc. Exp. Biol. Med. 142:842-845.

16. Yasuda, N., M. A. Greer, S. E. Greer, and P. Panton. 1978. Studies on the site of action of vasopressin in inducing adrenocorticotropin secretion. Endocrinology. 103:906-911.

17. McDonald, R. K., and V. K. Weise. 1956. Effect of argininevasopressin and lysine-vasopressin on plasma 17-hydroxycorticosteroid levels in man. Proc. Soc. Exp. Biol. Med. 92:481-483.

18. Staub, J. J., J. S. Jenkins, J. G. Ratcliffe, and J. Landon. 1973. Comparison of corticotrophin and corticosteroid response to lysine vasopressin, insulin and pyrogen in man. Br. Med. J. 1:267-269.

19. Pearlmutter, A. F., L. Dokar, A. Kong, R. Miller, and M. S. Saffran. 1980. Is corticotropin releasing factor modulated vasopressin? Nature (Lond.). 283:697-698.

20. Gillies, G., and P. J. Lowry. 1982. Corticotropin-releasing hormone and its vasopressin component. Front. Neuroendocrinol. 7:4575.

21. Gillies, G., and P. J. Lowry. 1980. Corticotrophin releasing activity in extracts of the stalk median eminence of Brattleboro rats. J. Endocrinol. 84:65-73.

22. Buckingham, J. C. 1981. The influence of vasopressin on hypothalamic corticotrophin releasing activity in rats with inherited diabetes insipidus. J. Physiol. (Lond.). 312:9-16.

23. Conte-Devolx, B., C. Oliver, P. Giraud, E. Castanas, F. Boudouresque, P. Gillioz, and Y. Millet. 1982. Adrenocorticotropin, $\beta$-endorphin, and corticosterone secretion in Brattleboro rats. Endocrinology. 110:2097-2100.

24. Gillies, G., and P. J. Lowry. 1979. Corticotrophin releasing factor may be modulated vasopressin. Nature (Lond.). 278:463-464. 
25. Yates, F. E., S. M. Russell, M. F. Dallman, G. A. Hedge, S. M. McCann, and A. P. S. Dhariwal. 1971. Potentiation by vasopressin of corticotropin release induced by corticotropin releasing factor. Endocrinology. 88:3-15.

26. Giguere, V., and F. Labrie. 1982. Vasopressin potentiates cyclic AMP accumulation and ACTH release induced by corticotropin-releasing factor (CRF) in rat anterior pituitary cells in culture. Endocrinology. 111:1752-1754.

27. Nicholson, W. E., D. R. Davis, B. J. Sherrelli, and D. N. Orth. 1984. Rapid radioimmunoassay for corticotropin in unextracted human plasma. Clin. Chem. In press.

28. Steele, R. G. D., and J. H. Torrie. 1960. Principles and Procedures of Statistics. McGraw-Hill, Inc., New York. 99-131.

29. Rivier, C., M. Brownstein, J. Spiess, J. Rivier, and W. Vale.
1982. In vivo corticotropin-releasing factor-induced secretion of adrenocorticotropin, $\beta$-endorphin, and corticosterone. Endocrinology. 110:272-278.

30. Hedge, G. A., M. B. Yates, R. Marcus, and F. E. Yates. 1966. Site of action of vasopressin in causing corticotropin release. Endocrinology. 79:328-340.

31. Shibahara, S., Y. Morimoto, J. Furutani, M. Notake, H. Takahashi, S. Shimizu, S. Horikawa, and S. Numa. 1983. Isolation and sequence analysis of the human corticotropin-releasing factor precursor gene. EMBO (Eur. Mol. Biol. Organ.) J. 2:775-779.

32. Spiess, J., J. Rivier, and W. Vale. 1983. Sequence analysis of rat hypothalamic corticotropin-releasing factor with the orthophthaldealdehyde strategy. Biochemistry. 22:4341-4346. 